EXPERIMENTAL STUDY

\title{
Growth hormone affects both adiposity and voluntary food intake in old and obese female rats
}

\author{
Kjell Malmlöf, Nanni Din ${ }^{1}$, Thue Johansen and Steen B Pedersen ${ }^{2}$ \\ Departments of Pharmacology 3 and ${ }^{1}$ Molecular Genetics, Novo Nordisk, Målov and ${ }^{2}$ Department of Internal Medicine, Aarhus University Hospital, \\ Amtssygehus, Aarhus, Denmark \\ (Correspondence should be addressed to K Malmlöf, Novo Nordisk A/S, Novo Nordisk Park, 2760 Målov, Denmark; Email: kmal@novonordisk.com)
}

\begin{abstract}
Objective: To investigate whether the promotion of breakdown of body fat and the increased energy expenditure associated with growth hormone $(\mathrm{GH})$ affect the voluntary food intake of an obese organism.

Design: Wistar rats (15 months old) were first fed either a high-fat (HF) or a low-fat (LF) diet for 10 weeks. In the subsequent treatment period, two saline groups continued with either the HF or the LF diet, and rats of three other groups had their diet shifted from HF to LF and were treated with saline, human $\mathrm{GH}(\mathrm{hGH})$ or rat $\mathrm{GH}$ (rGH). hGH and rGH were given in a dose of $4 \mathrm{mg} / \mathrm{kg}$ per day. After 21 days of treatment and registration of food intake, rats were killed, blood was collected and tissues were excised.

Results: The HF diet produced a significant $(P<0.05)$ increase in weight of fat pads compared with the LF diet: $69 \pm 5 \mathrm{~g}$ compared with $48 \pm 2 \mathrm{~g}$. The switch from HF to LF diet combined with injections of saline alone decreased the intake of metabolizable energy, but fat pad weight did not decrease significantly $(69 \pm 5 \mathrm{~g}$ compared with $63 \pm 6 \mathrm{~g})$. The latter value was significantly $(P<0.05)$ decreased (to $37 \pm 3 \mathrm{~g}$ ) in groups treated with either hGH or rGH. Both GH treatments increased serum IGF-I and muscle weight, whereas the activity of adipose tissue lipoprotein lipase decreased significantly $(P<$ 0.01). During the first 9 days of treatment, food intake was significantly $(P<0.01)$ depressed, from $27 \pm 1 \mathrm{~g} / \mathrm{kg}$ per day in control rats to $14 \pm 2$ and $16 \pm 4 \mathrm{~g} / \mathrm{kg}$ per day in the hGH and rGH groups respectively.

Conclusion: This study demonstrates that breakdown of adipose tissue and a transient decrease in voluntary food intake are parallel consequences of GH treatment in old and obese rats, and that the actions of hGH and rGH are very similar.
\end{abstract}

European Journal of Endocrinology 146 121-128

\section{Introduction}

It is established that growth hormone $(\mathrm{GH})$ has a potential to reduce fat mass in obese adults $(1-6)$. These effects are most probably preceded by increases in metabolic rate and energy expenditure (7-9). At present, very little is known of whether the GH-mediated alterations in energy metabolism are associated with changes in voluntary food intake, in humans. Results from experiments performed in laboratory rats imply that GH stimulates food intake $(10,11)$. However, these experiments were performed in non-obese and comparatively young rats. In this type of animal, $\mathrm{GH}$ has been found to stimulate body protein accretion significantly (12), thereby also increasing both protein and energy requirements. This might explain the increase in food intake seen. In an older organism, in which the capacity for lean tissue growth is naturally more limited and the amount of energy stored in fat depots is much greater, the calorigenic action of $\mathrm{GH}$ might represent a substantial metabolic challenge, the problem being to find a use for the energy delivered from endogenous stores. It cannot be excluded that, in such a situation, administration of GH could be associated with a decrease in voluntary food intake as a way to maintain energy homeostasis.

The main aim of the present work was to investigate the hypothesis that $\mathrm{GH}$ administration might decrease food intake, along with fat depots, in an old and obese but otherwise normal rat. From a methodological point of view, we were also interested to learn whether human $\mathrm{GH}$ and rat $\mathrm{GH}$ had the same effects in this type of animal model.

\section{Materials and methods}

\section{Animals and test substances}

Female Wistar rats weighing about $300 \mathrm{~g}$ were purchased 1 month before the start of experiments, from 
Table 1 Composition of HF and LF diets.

\begin{tabular}{lrr}
\hline & \multicolumn{2}{c}{ Diet } \\
\cline { 2 - 3 } Contents & HF & LF \\
\hline Ingredients $(\mathrm{g} / \mathrm{kg})$ & & \\
$\quad$ Corn meal & 493 & 818 \\
Wheat bran & 27 & 27 \\
Casein & 148 & 110 \\
Animal fat & 300 & 13 \\
$\quad$ Vitamin and minerals & 32 & 32 \\
Chemical composition (g/kg) & 170 & 170 \\
$\quad$ Crude protein & 320 & 50 \\
Crude fat & 4.8 & 3.2 \\
Metabolizable energy (MCal/kg) & & \\
Fatty acids (\% of crude fat) & 49 & 25 \\
$\quad$ Saturated & 39 & 30 \\
Monounsaturated & 12 & 46 \\
Polyunsaturated & 34 & 28 \\
$\quad$ Oleic acid & 94 & 92 \\
$\quad$ Total fatty acids & & \\
\hline
\end{tabular}

Møllegård Breeding and Research Centre (Lille Skensved, Denmark). On receipt, rats were placed in conventional rat cages housing two or three animals. They were weighed weekly and had free access to drinking water and standard rat feed. All diets, including the experimental ones (Table 1) were purchased from a local feed manufacturer (Brogaarden, Gentofte, Denmark). The experiment was given ethics approval by the Animal Experiment Inspectorate (Dyreforsøgstilsynet, Copenhagen, Denmark). Recombinant hGH (Norditropin) was from Novo Nordisk A/S (Bagsværd, Denmark) and recombinant rat $\mathrm{GH}$ was purchased from Bresatec (Adelaide, Australia).

\section{Experimental procedures}

At the age of 15 months, rats were randomly assigned to receive either a high-fat (HF) $(n=45)$ or a low-fat (LF) diet $(n=22)$ (Table 1$)$. This 'fattening' period continued for 10 weeks, during which time the body weight development was recorded (Fig. 1). As dosing started, rats were assigned to five groups. One group of 12 animals that were fed the HF diet $(n=12)$ and all animals fed the LF diet $(n=22)$ were allowed to continue on their respective diets, and were injected with saline. In three other groups, the diet was shifted from HF to LF and subcutaneous injections of saline $(n=11)$, hGH $(n=11)$ or $\mathrm{rGH}(n=11)$ were started. During the entire experiment animals were kept in standard cages, housing two or three animals receiving the same treatment, and allowing a 'normal' environment with free access to food and water. The total daily dose $(4 \mathrm{mg} / \mathrm{kg})$ of $\mathrm{hGH}$ and $\mathrm{rGH}$ was divided in two equal parts which were given at 0800 and $1600 \mathrm{~h}$. Body weights were recorded at start of treatment, after 9 days, and at the end of the experiment after 21 days of treatment. The amount of food consumed during

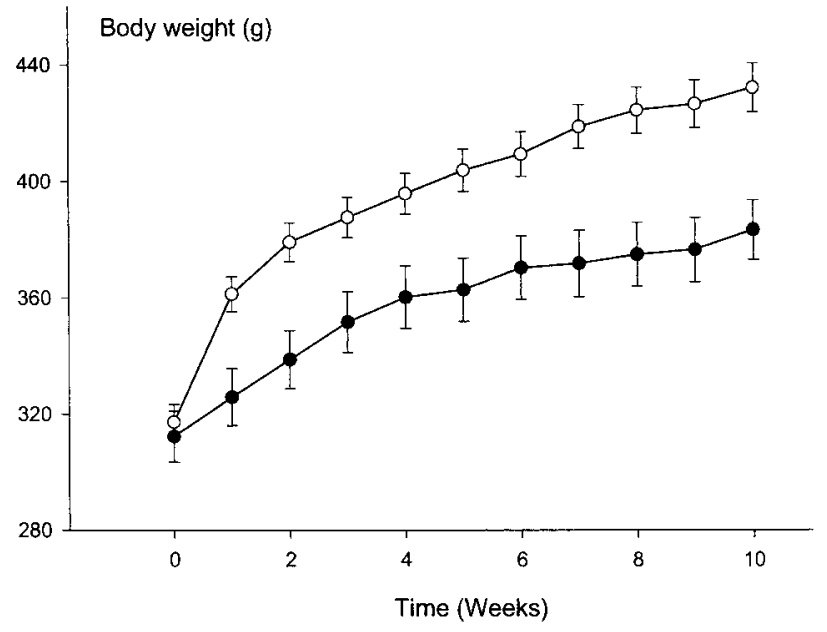

Figure 1 Body weight development before dosing in rats fed an $\mathrm{HF}(\mathrm{O}, n=52)$ or an LF $(\bullet, n=22)$ diet. Data represent means \pm S.E.

these time intervals was estimated by subtracting the residual food recovered from each cage from the total amount presented. On the last day of treatment, unanaesthetized animals were killed by decapitation. After bleeding, serum and plasma was prepared and frozen at $-80^{\circ} \mathrm{C}$.

Fat pads around uterus, ovaries and intestines were quickly dissected free and is collectively referred to as 'intra-abdominal fat'. The large fat pad outside the peritoneum, embedding the kidneys, was also dissected free and this is referred to as the 'peri-renal fat pad'. A welldefined subcutaneous fat pad attached to the femoral muscles was also dissected free. After dissection, fat pads were weighed and frozen at $-80^{\circ} \mathrm{C}$. One skeletal muscle (quadriceps femoris) was dissected out and weighed, before being dried at $+70^{\circ} \mathrm{C}$ for $24 \mathrm{~h}$, for determination of muscle dry matter.

\section{Chemical analyses}

The content of free fatty acids (FFA) in the diets was analysed by a commercial laboratory (Bioteknologisk Institut, Kolding, Denmark) using gas chromatography and using standardized methods. Serum concentrations of metabolites were analysed in an auto-analyser system Synchron CX5 (Beckman Instruments, Fullerton, CA, USA). Plasma amino acids were determined using an ion exchange chromatographic system, Biochrom 20 (Amersham Pharmacia Biotech, Cambridge, Cambs, UK). After separation, amino acids were allowed to react with ninhydrin. The between-run and withinrun coefficients of variation for the most abundant amino acids were less than $8 \%$. The term 'amino acids' used in the text refers to the 20 naturally occurring amino acids, except tryptophan, with specific tRNAs for incorporation in peptides and protein. 


\section{Hormone assays}

Total serum insulin-like growth factor (IGF)-I was measured after acid-ethanol extraction as previously described (13). The intra- and interassay coefficients of variation were $6 \%$ and $13 \%$ respectively. Serum insulin was analysed with an assay described previously (14). The intra- and interassay assay coefficients of variation for this assay were $8.4 \%$ and $5.4 \%$ respectively. Serum leptin was analysed with a commercial kit from Linco Research, Inc. (St Charles, MO, USA). Intra- and interassay coefficients of variation were $5.7 \%$ and $4.6 \%$ respectively. Analyses of serum thyroxin $\left(\mathrm{T}_{4}\right)$ and triiodothyronine $\left(\mathrm{T}_{3}\right)$ were performed by Dr Forsberg (Department of Clinical Chemistry, Veterinary Faculty, Uppsala, Sweden), using RIA kits from DPC (Los Angeles, CA, USA). The intra- and interassay coefficients of variation for these analyses were all less than $6 \%$.

\section{Lipoprotein lipase assay}

Lipoprotein lipase (LPL) activity was analysed in perirenal fat pads, with a method previously described (2). Briefly, the activity of LPL was measured as the amount of hydrolysed $\left[{ }^{14} \mathrm{C}\right]$ triolen after incubation of $0.1 \mathrm{ml}$ eluted enzyme with $0.1 \mathrm{ml}$ substrate for $1 \mathrm{~h}$ at $37^{\circ} \mathrm{C}$, and was expressed as c.p.m./mg protein per h. The intra-assay coefficient of variation was $8 \%$.

\section{Statistical analyses}

All experimental data were entered into the 6.11 version of the SAS statistical software program, in which descriptive statistics were calculated using the univariate procedure (SAS Inc., Cary, NC, USA). Before further analyses, data were checked for normal distribution. In some cases in which deviations were found, data were logarithmically transformed to achieve a normal distribution. Potential differences between treatment groups were tested with a one-way analysis of variance (GLM procedure of SAS) followed by Duncan's multiple-range test. In most cases, these tests were performed with an alpha value of 0.05 , but where applicable a value of 0.01 was used. Data are presented as means \pm S.E.

\section{Results}

\section{Body weight gain}

As can be seen in Fig. 1, rats in the two diet groups began with similar body weights, but when rats were introduced to the HF diet there was a rapid increase in body weight. Over a 10-week 'fattening' period, they gained $115 \pm 5 \mathrm{~g}$. Rats given the LF diet gained $72 \pm$ $5 \mathrm{~g}$, which was significantly $(P<0.01)$ lower. This resulted in significant $(P<0.01)$ differences in live weights $(434 \pm 8 \mathrm{~g}$ in the HF group and $384 \pm 11 \mathrm{~g}$ in the LF group) at the end of the 10-week period. During dosing, all groups except that given the $\mathrm{HF}$ diet appeared to lose somewhat in body weight, but no significant differences were found between groups (Table 2).

\section{Body composition}

The total weight of fat pads excised were respectively $69 \pm 5 \mathrm{~g}$ and $48 \pm 2 \mathrm{~g}$, in animals given the $\mathrm{HF}$ and the LF diet (Table 2). When change of diet was combined

Table 2 Effects of HF and LF diets and of hGH and rGH on body weight and the weight of skeletal muscle (quadriceps femoris; QF) and fat pads. Data are presented as means \pm S.E.

\begin{tabular}{|c|c|c|c|c|c|}
\hline \multirow[b]{3}{*}{ Type of dosing: } & \multicolumn{5}{|c|}{ Diets before/during dosing } \\
\hline & \multirow{2}{*}{ 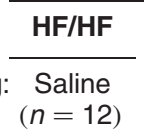 } & \multirow{2}{*}{$\begin{array}{c}\text { LF/LF } \\
\begin{array}{c}\text { Saline } \\
(n=22)\end{array}\end{array}$} & \multicolumn{3}{|c|}{ HF/LF } \\
\hline & & & $\begin{array}{l}\text { Saline } \\
(n=11)\end{array}$ & $\begin{array}{c}\text { hGH } \\
(n=11)\end{array}$ & $\begin{array}{c}\mathrm{rGH} \\
(n=11)\end{array}$ \\
\hline \multicolumn{6}{|l|}{ Body weights (g) } \\
\hline Start weight & $433 \pm 19^{a}$ & $384 \pm 11^{b}$ & $429 \pm 18^{a}$ & $434 \pm 16^{a}$ & $439 \pm 14^{a}$ \\
\hline Final weight & $436 \pm 19^{a}$ & $376 \pm 9^{b}$ & $410 \pm 20^{a b}$ & $428 \pm 15^{a}$ & $417 \pm 11^{\mathrm{ab}}$ \\
\hline Change in weight & $2.6 \pm 4^{a}$ & $-7.9 \pm 3^{a}$ & $-18.8 \pm 4^{a}$ & $-6.2 \pm 15^{a}$ & $-21.2 \pm 20^{\mathrm{a}}$ \\
\hline \multicolumn{6}{|l|}{ Organs } \\
\hline QF muscle (g) & $2.2 \pm 0.1^{\mathrm{b}}$ & $2.2 \pm 0.0^{\mathrm{b}}$ & $2.1 \pm 0.1^{\mathrm{b}}$ & $2.7 \pm 0.1^{\mathrm{a}}$ & $2.5 \pm 0.1^{\mathrm{a}}$ \\
\hline Dry QF (mg) & $622 \pm 21^{b}$ & $616 \pm 14^{\mathrm{b}}$ & $594 \pm 32^{b}$ & $721 \pm 35^{a}$ & $670 \pm 37^{\mathrm{ab}}$ \\
\hline Liver $(\mathrm{g})$ & $10.6 \pm 0.5^{b}$ & $9.6 \pm 0.2^{\mathrm{b}}$ & $9.2 \pm 0.4^{b}$ & $14.9 \pm 0.7^{a}$ & $14.8 \pm 0.7^{a}$ \\
\hline \multicolumn{6}{|l|}{ Fat pads $(\mathrm{g})$} \\
\hline Peri-renal & $22 \pm 2^{a}$ & $14 \pm 1^{b}$ & $21 \pm 3^{a}$ & $10 \pm 2^{b}$ & $10 \pm 1^{b}$ \\
\hline Intra-abdominal & $45 \pm 3^{a}$ & $33 \pm 2^{b}$ & $41 \pm 3^{a}$ & $26 \pm 1^{b}$ & $27 \pm 2^{b}$ \\
\hline Subcutaneous & $1.6 \pm 0.1^{\mathrm{a}}$ & $0.7 \pm 0.1^{c}$ & $1.1 \pm 0.1^{\mathrm{b}}$ & $0.7 \pm 0.1^{c}$ & $0.7 \pm 0.1^{\mathrm{c}}$ \\
\hline Sum & $69 \pm 5^{\mathrm{a}}$ & $48 \pm 2^{\mathrm{b}}$ & $63 \pm 6^{a}$ & $37 \pm 3^{b}$ & $37 \pm 3^{\mathrm{b}}$ \\
\hline
\end{tabular}

Differences between groups were tested with one-way analysis of variance followed by Duncan's multiple range test. Values within rows not sharing a common superscript letter differ significantly $(P<0.05)$. 
with saline alone, the corresponding figure was $63 \pm 6 \mathrm{~g}$, but if either hGH or rGH was injected instead of saline then the amount of adipose tissue decreased significantly $(P<0.05)$, to $37 \pm 3 \mathrm{~g}$ in both groups. In parallel, fresh liver and muscle (quadriceps femoris) weights increased significantly $(P<0.05)$. After the whole muscle was dried, this effect remained significant $(P<$ 0.05 ) in the hGH group, but not in the rGH group. The differences in body composition evoked by both $\mathrm{GH}$ treatments also remained the same when organ and tissue weights were expressed in relation to body weight (Fig. 2).

\section{Food intake}

It was found that a shift of diet from HF to LF combined with injections of saline alone did not in itself affect food intake, but when rats were treated with hGH or $\mathrm{rGH}$, instead of saline, they responded with a marked hypophagia (Table 3). This effect was very pronounced up to 9 days of treatment, but disappeared in the period between 9 and 21 days (Fig. 3).

\section{Plasma variables}

During treatment with hGH, circulating concentrations of FFA and amino acids increased significantly $(P<$ 0.05) (Table 4). Treatment with rGH seemed to move these variables in the same direction, but these effects were not statistically significant. Circulating urea concentrations decreased significantly $(P<0.05)$ after treatment with both GH variants. Glucose was unchanged, but insulin increased dramatically $(P<$ $0.05)$, from $286 \pm 47 \mathrm{pmol} / \mathrm{l}$ in the control group to $1006 \pm 210$ and $1230 \pm 250 \mathrm{pmol} / \mathrm{l}$ in the $\mathrm{hGH}$ and $\mathrm{rGH}$ groups respectively. This was associated with significant $(P<0.05)$ increases in serum concentrations of IGF-I. Leptin concentrations tended to decrease during both GH treatments and were approaching the values found in animals that had received the LF diet throughout. This trend was statistically significant $(P<$ 0.05 ) for animals treated with rGH. Both hGH and rGH increased the serum concentrations of $\mathrm{T}_{4}$ significantly $(P<0.05)$, whereas $\mathrm{T}_{3}$ remained unchanged (Table 4$)$.

\section{Activity of LPL}

In the control group in which diet was changed from HF to LF and saline alone was injected, the LPL activity of the peri-renal fat pad was $4343 \pm 654$ c.p.m./mg protein per $\mathrm{h}$ (Fig. 4). hGH and rGH decreased this figure to $1919 \pm 272$ and $2435 \pm 525$ c.p.m./mg protein per $\mathrm{h}$ respectively. The decrease was statistically significant $(P<0.01)$ in both cases. The total amount of protein in the peri-renal fat pad remained relatively unchanged, despite the differences in the weight (data not shown).
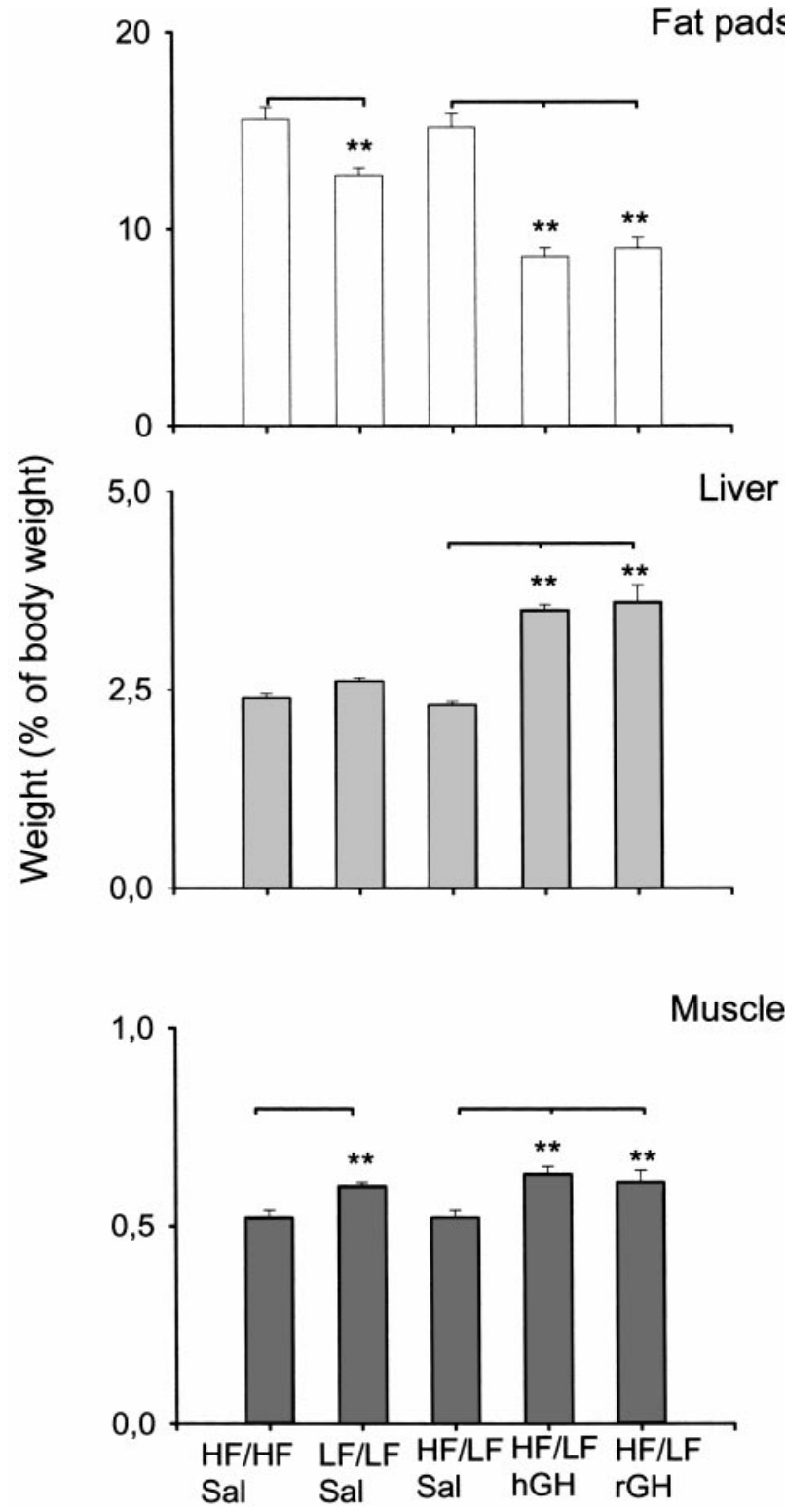

Figure 2 Relative fresh tissue weights of fat pads, liver and muscle (quadriceps femoris). Rats were first fed an HF or an LF diet for 10 weeks. At start of dosing, all rats receiving $\mathrm{GH}$ and one saline (Sal) group were switched from the HF diet to the LF diet (HF/LF). Others continued on their diets (HF/HF, LF/LF). hGH and $\mathrm{rGH}$ were injected subcutaneously in a daily dose of $4 \mathrm{mg} / \mathrm{kg}$ for 21 days. Data are expressed as (fresh tissue/ body weight) $X$ 100 and represent means \pm S.E. $(n=11-22) .{ }^{*} P<0.01$ : significant differences between groups (one-way analysis of variance followed by Duncan's multiple range test).

\section{Discussion}

In this study it was found that an HF diet containing $32 \%$ of fat promoted adiposity in normal rats when given over an extended period of time. When the fat rats were switched over to an LF diet, their consumption of metabolizable energy decreased, but no major 
Table 3 Effects of HF and LF diets and of hGH and rGH on food consumption. Food intake was registered and analysed per cage unit, which contained two or three animals. Data are presented as means \pm S.E.

\begin{tabular}{|c|c|c|c|c|c|}
\hline \multirow{3}{*}{ Type of dosing: } & \multicolumn{5}{|c|}{ Diets before/during dosing } \\
\hline & \multirow{2}{*}{$\begin{array}{l}\text { HF/HF } \\
\begin{array}{l}\text { Saline } \\
(n=6)\end{array}\end{array}$} & \multirow{2}{*}{$\begin{array}{c}\text { LF/LF } \\
\begin{array}{c}\text { Saline } \\
(n=10)\end{array}\end{array}$} & \multicolumn{3}{|c|}{ HF/LF } \\
\hline & & & $\begin{array}{l}\text { Saline } \\
(n=5)\end{array}$ & $\begin{array}{c}\text { hGH } \\
(n=5)\end{array}$ & $\begin{array}{c}\text { rGH } \\
(n=5)\end{array}$ \\
\hline \multicolumn{6}{|l|}{ Intakes } \\
\hline Food (g/day) & $12.9 \pm 0.4^{a}$ & $14.1 \pm 0.4^{a}$ & $11.9 \pm 0.6^{\mathrm{a}}$ & $8.7 \pm 0.8^{b}$ & $8.7 \pm 1.5^{b}$ \\
\hline Food (g/kg per day) & $29.9 \pm 1.1^{\mathrm{b}}$ & $37.0 \pm 1.5^{\mathrm{a}}$ & $28.2 \pm 1.1^{\mathrm{b}}$ & $20.0 \pm 2.2^{c}$ & $20.9 \pm 3.9^{c}$ \\
\hline ME (Cal/kg per day) & $144 \pm 5.1^{\mathrm{a}}$ & $120 \pm 4.9^{b}$ & $92 \pm 0.2^{c}$ & $65 \pm 7.3^{d}$ & $68 \pm 12.7^{d}$ \\
\hline Protein (g/kg per day) & $5.1 \pm 0.2^{\mathrm{b}}$ & $6.3 \pm 0.3^{a}$ & $4.8 \pm 0.2^{b}$ & $3.4 \pm 0.4^{\mathrm{C}}$ & $3.6 \pm 0.7^{c}$ \\
\hline
\end{tabular}

ME, Metabolizable engergy.

Differences between groups were tested with one-way analysis of variance followed by Duncan's multiple range test. Values within rows not sharing a common superscript letter differ significantly $(P<0.05)$.

changes in fat pad weights were seen. This observation confirms that the effect of energy restriction alone on fat mass is a slow process (15). However, if shift of diet was combined with injections of either hGH or $\mathrm{rGH}$, loss of fat mass was significantly accelerated: after 3 weeks of treatment, the fat pad weights were comparable to those of rats that had been on an LF regimen throughout. Thus the surplus fat accumulated during the "fattening' period had been broken down, confirming that GH is a potent regulator of body fat mass in old but genetically intact obese rats. Similar results have been found in studies performed in obese Zucker rats (16, 17 ) and in humans (1-6). Moreover, from a methodological point of view, it is of great importance that rGH and hGH had more or less identical effects. It implies that either of the two GH variants can be used for studies in the current rat model. The nearly identical response in plasma IGF-I concentration further supports this conclusion.

In parallel with the changes in body fat, both $\mathrm{GH}$ variants caused a slight increase in muscle mass in terms of wet weight, which is in line with what has been reported from studies with younger rats (18). Muscle dry matter was also increased by hGH, and rGH produced results of a similar nature. It is of note that the ingestion of dietary protein was not increased in GH-treated animals. The increase in muscle mass must, therefore, have been dependent on an increased efficiency of conversion of dietary protein to tissue protein. One reason for this could be that GH is known to decrease the hepatic conversion of plasma amino acids to urea (19), which up-regulates the concentrations of circulating amino acids and favours their peripheral uptake (20). Accordingly, a decrease in circulating urea and an increase in plasma amino acids were observed in both GH-treated groups. Thus, under the experimental conditions of the present study, GH exerted both lipolytic and protein anabolic actions.

The dramatic reduction of adipose tissue weight in the GH groups was associated with a decrease in the activity of LPL, the enzyme responsible for the hydrolysis of triacylglycerol delivered to tissues in the form of

Table 4 Effects of HF and LF diets and of hGH and rGH on serum and plasma variables. Data are presented as means \pm S.E.

\begin{tabular}{|c|c|c|c|c|c|}
\hline \multirow[b]{3}{*}{ Type of dosing: } & \multicolumn{5}{|c|}{ Diets before/during dosing } \\
\hline & \multirow{2}{*}{$\begin{array}{l}\text { HF/HF } \\
\begin{array}{c}\text { Saline } \\
(n=12)\end{array}\end{array}$} & \multirow{2}{*}{$\begin{array}{c}\text { LF/LF } \\
\text { Saline } \\
(n=22)\end{array}$} & \multicolumn{3}{|c|}{ HF/LF } \\
\hline & & & $\begin{array}{c}\text { Saline } \\
(n=11)\end{array}$ & $\begin{array}{c}\text { hGH } \\
(n=11)\end{array}$ & $\begin{array}{c}\mathrm{rGH} \\
(n=11)\end{array}$ \\
\hline \multicolumn{6}{|l|}{ Metabolites (mmol/l) } \\
\hline FFA & $0.5 \pm 0.05^{\mathrm{ab}}$ & $0.4 \pm 0.04^{b}$ & $0.4 \pm 0.05^{\mathrm{b}}$ & $0.6 \pm 0.07^{\mathrm{a}}$ & $0.4 \pm 0.08^{\mathrm{at}}$ \\
\hline Glucose & $6.9 \pm 0.8^{\mathrm{a}}$ & $6.8 \pm 0.1^{\mathrm{a}}$ & $6.6 \pm 0.1^{\mathrm{a}}$ & $6.4 \pm 0.2^{\mathrm{a}}$ & $6.9 \pm 0.4^{\mathrm{a}}$ \\
\hline Urea & $5.8 \pm 0.2^{\mathrm{a}}$ & $6.4 \pm 0.2^{\mathrm{a}}$ & $5.8 \pm 0.3^{a}$ & $4.0 \pm 0.3^{b}$ & $4.1 \pm 0.4^{b}$ \\
\hline Amino acids & $4.4 \pm 0.2^{\mathrm{ab}}$ & $4.1 \pm 0.2^{b}$ & $4.1 \pm 0.3^{\mathrm{b}}$ & $5.0 \pm 0.3^{a}$ & $4.5 \pm 0.3^{\mathrm{ab}}$ \\
\hline \multicolumn{6}{|l|}{ Hormones } \\
\hline IGF-I ( $\mu \mathrm{mol} / \mathrm{I})$ & $336 \pm 30^{b}$ & $343 \pm 16^{b}$ & $333 \pm 22^{b}$ & $772 \pm 68^{a}$ & $791 \pm 55^{\mathrm{a}}$ \\
\hline Insulin (pmol/l) & $357 \pm 121^{\mathrm{b}}$ & $378 \pm 62^{b}$ & $286 \pm 47^{b}$ & $1006 \pm 210^{\mathrm{a}}$ & $1230 \pm 250^{\mathrm{a}}$ \\
\hline Leptin $(\mu \mathrm{g} / \mathrm{l})$ & $33 \pm 4^{\mathrm{a}}$ & $22 \pm 1^{b}$ & $29 \pm 3^{a b}$ & $25 \pm 5^{\mathrm{ab}}$ & $21 \pm 2^{b}$ \\
\hline $\mathrm{T}_{4}(\mathrm{nmol} / \mathrm{l})$ & $42 \pm 3^{b}$ & $41 \pm 1^{\mathrm{b}}$ & $38 \pm 1^{\mathrm{b}}$ & $87 \pm 4^{\mathrm{a}}$ & $88 \pm 3^{a}$ \\
\hline $\mathrm{T}_{3}(\mathrm{nmol} / \mathrm{l})$ & $0.9 \pm 0.09^{a}$ & $0.8 \pm 0.04^{a}$ & $0.8 \pm 0.07^{a}$ & $0.8 \pm 0.11^{a}$ & $0.6 \pm 0.8^{\mathrm{a}}$ \\
\hline
\end{tabular}

Differences between groups were tested with one-way analysis of variance followed by Duncan's multiple range test. Values within rows not sharing a common superscript letter differ significantly $(P<0.05)$. 


\section{Days 0-9}
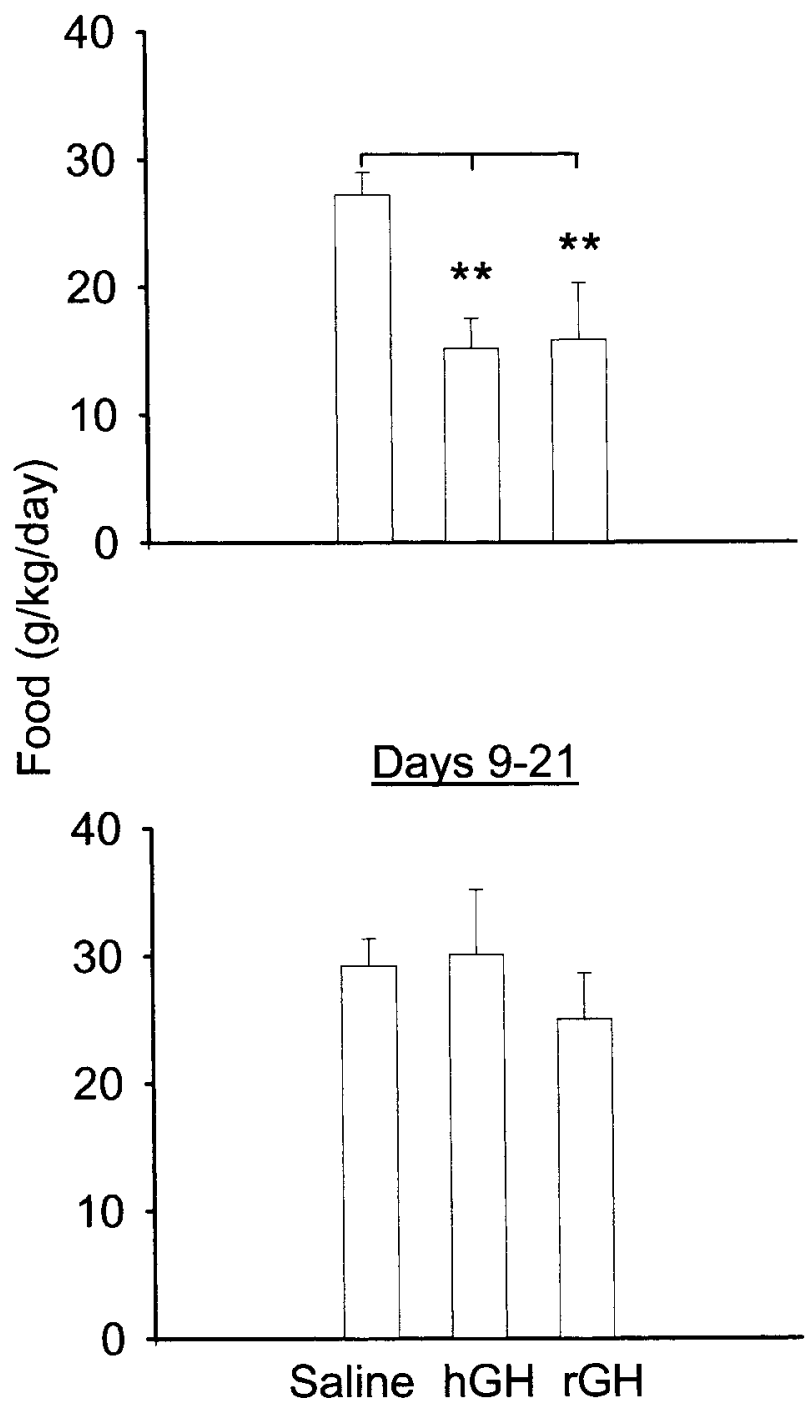

Figure 3 Food intake in a first (days 0-9) and second (days 921) period of treatment with $\mathrm{hGH}, \mathrm{rGH}$ or saline. Rats were first fed an HF diet for 10 weeks. As dosing started, they were switched to an LF diet. The daily dose of $\mathrm{GH}$ was $4 \mathrm{mg} / \mathrm{kg}$ in all cases. Injections were performed subcutaneously for 21 days. ${ }^{* \star} P<0.01$ : significant differences between groups (one-way analysis of variance followed by Duncan's multiple range test).

very-low-density lipoprotein particles and chylomicrons circulating in the blood $(21,22)$. The same effect of GH on LPL activity has been observed in humans (2). Thus one explanation as to why $\mathrm{GH}$ decreases fat pad weight might be that the entry of FFA into fat depots is significantly decreased.

It is believed that GH increases the release of FFA from adipose tissue (3), but in the present study circulating FFA concentrations were only slightly increased by GH

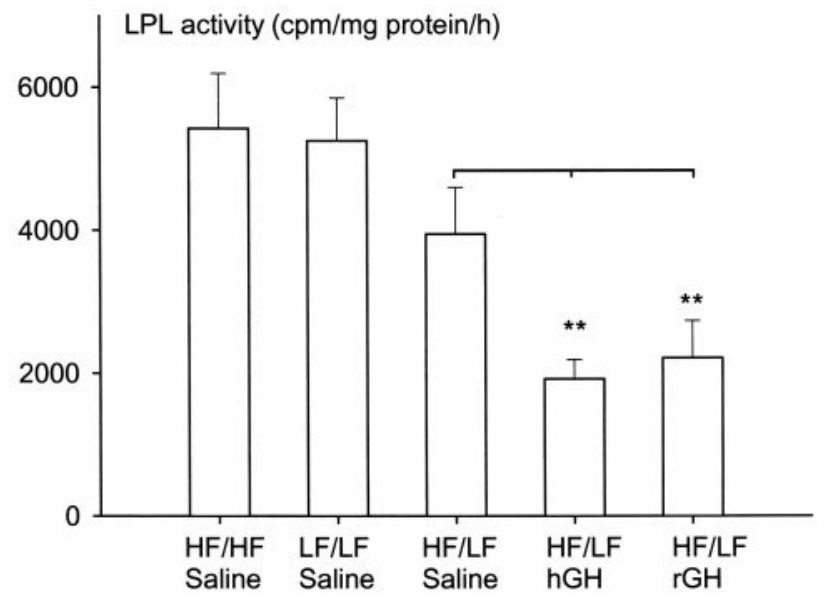

Figure $4 \mathrm{LPL}$ activity of peri-renal adipose tissue in rats. Rats were first fed an HF or an LF diet for 10 weeks. At start of dosing, all rats receiving $\mathrm{GH}$ and one saline group were switched from the $\mathrm{HF}$ to the LF diet (HF/LF). Other rats continued on their diets (HF/HF, LF/LF). hGH and rGH were injected subcutaneously in a daily dose of $4 \mathrm{mg} / \mathrm{kg}$ for 21 days. Data represent means \pm S.E. ( $n=11-22)$. ${ }^{* *} P<0.01$ : significant differences between groups (one-way analysis of variance followed by Duncan's multiple range test).

treatment. There could be several explanations for this. The most simple could be that blood samples were taken on the last day of dosing. At that time, the fat pads were already normalized and probably, therefore, plasma FFA concentrations also. An increase in the turnover of plasma FFA could be another explanation. Livers of GH-treated animals increased significantly in weight and could be a sign of an increased hepatic uptake of FFA. The composition of the liver after GH treatment is unknown, but increases in liver size have previously been observed in GH-treated obese Zucker rats $(16,17)$.

Perhaps the most remarkable finding of the present study was that the administration of both GH variants also caused an immediate and marked decrease in food intake, which diminished only gradually, in the first phase of GH treatment. This is in contrast to the findings of earlier studies in which younger animals were used (10-12). A stimulatory effect on food intake has also been seen in GH-treated children (23). To our knowledge, a hypophagic effect of GH in rats is an original finding and verifies our original hypothesis that the effect of $\mathrm{GH}$ on food intake might differ between aged obese animals and younger lean ones. In order to verify this further, young female Wistar rats were given the same dose of hGH as used in the present study (data not shown). It was found that rats responded with a significant increase in food intake shortly after initiation of GH treatment.

For various reasons, the effects of $\mathrm{GH}$ on the voluntary food intake in obese humans is a poorly explored area. In many studies, participants were receiving a 
specific dietary regimen $(3,6)$, or estimates of food intake were based on self-reporting $(1,23)$. It is, however, of note that a decline in appetite after the injection of $\mathrm{GH}$ has been observed in pigs in late growth phase (24), and in dairy cows (25). It could be suspected that the pigs studied by Roberts \& Azain (24), with body weights between 69 and $100 \mathrm{~kg}$, had already accumulated a considerable amount of fat.

On a general physiological level, it could be speculated that the hypophagic response results from an imbalance between the amounts of energy released during breakdown of fat reserves on one side, and the energy requirement of the protein synthetic machinery on the other. If this hypothesis is correct, such an imbalance is more likely to occur in an aged organism with a large fat reserve combined with a low protein anabolic potential than in a younger organism with a small fat reserve and high protein anabolic drive (26) - which, in addition, is further stimulated by GH (12). In the present study, the observation that food intake normalized later on during $\mathrm{GH}$ treatment when fat reserves had been discharged could fit this hypothesis, and the fact that younger GH-treated rats do not show hypophagia.

In future studies, it will be interesting to explore in more detail the pathways that are involved in the hypophagic effect of GH. In the present work, a decrease in leptin was seen in GH-treated animals. Although leptin might be an important factor measurements were made on samples obtained on the very last day of experiments when food intake was normalized. It would be very interesting to obtain information relating to the leptin concentration of samples taken shortly after commencement of $\mathrm{GH}$ treatment, when the effects on food intake are most pronounced. The same is true for the somewhat puzzling results obtained for $\mathrm{T}_{4}$ and $\mathrm{T}_{3}$, namely that $\mathrm{T}_{3}$ unexpectedly remained unchanged by $\mathrm{GH}(7,8)$ and $\mathrm{T}_{4}$ was increased. Studies focused on the first period of $\mathrm{GH}$ treatment are therefore planned.

GH treatment did not change serum glucose, but circulating concentrations of both insulin and IGF-I were massively increased, more or less to the same degree with both GH variants. These are well known effects of $\mathrm{GH}$, and imply that $\mathrm{GH}$ reinforces insulin resistance (14) in the obese state. At least one study in humans suggests that prolonged GH treatment leads to improvements of insulin sensitivity (4). The animal model presented in the present work appears to be well suited to further exploration of this critical point.

In conclusion, this study demonstrates that breakdown of adipose tissue and a transient decrease in voluntary food intake are parallel consequences of $\mathrm{GH}$ treatment in old and obese rats, whereas muscle mass is preserved or increased. The mechanism by which these very interesting changes are brought about requires clarification before the therapeutic benefits can be fully envisaged.

\section{Acknowledgements}

We thank Mrs Hanne Jepsen, technician responsible for this experiment, and Mrs Anne Trolle-Christensen and Mrs Helle Francker-Pedersen for their excellent technical assistance. We also thank Dr Karin Rimvall for running the leptin analyses. This study was performed with funding from Danish Medical Research Council and the Novo Nordisk Foundation.

This work was presented in part as an abstract at the 4th Growth Hormone Research Society Conference, GRS 2000, Gothenburg, Sweden 2000.

\section{References}

1 Skaggs SR \& Crist DM. Exogenous human growth hormone reduces body fat in obese women. Hormone Research 199135 19-24.

2 Richelsen B, Pedersen SB, Borglum JD, Moller-Pedersen T, Jorgensen J \& Jorgensen JO. Growth hormone treatment of obese women for $5 \mathrm{wk}$ : effect on body composition and adipose tissue LPL activity. American Journal of Physiology $1994 \mathbf{2 6 6}$ E211-E216.

3 Snyder DK, Underwood LE \& Clemmons DR. Persistent lipolytic effect of exogenous growth hormone during caloric restriction. American Journal of Medicine 199598 129-134.

4 Johannsson G, Marin P, Lonn L, Ottosson M, Stenlof K, Bjorntorp P et al. Growth hormone treatment of abdominally obese men reduces abdominal fat mass, improves glucose and lipoprotein metabolism, and reduces diastolic blood pressure. Journal of Clinical Endocrinology and Metabolism 199782 727-734.

5 Cuneo RC, Judd S, Wallace JD, Perry-Keene D, Burger H, Lim-Tio S et al. The Australian multicenter trial of growth hormone (GH) treatment in GH-deficient adults. Journal of Clinical Endocrinology and Metabolism $1998 \mathbf{8 3} 107-116$.

6 Kim KR, Nam SY, Song YD, Lim SK, Lee HC \& Huh KB. Low-dose growth hormone treatment with diet restriction accelerates body fat loss, exerts anabolic effect and improves growth hormone secretory dysfunction in obese adults. Hormone Research 1999 $5178-84$

7 Jorgensen JO, Pedersen SB, Borglum J, Moller N, Schmitz O, Christiansen JS et al. Fuel metabolism, energy expenditure, and thyroid function in growth hormone-treated obese women: a double-blind placebo-controlled study. Metabolism $1994 \mathbf{4 3}$ 872-877.

8 Wolthers T, Groftne T, Moller N, Christiansen JS, Orskov H, Weeke J et al. Calorigenic effects of growth hormone: the role of thyroid hormones. Journal of Clinical Endocrinology and Metabolism 1996 81 1416-1419.

9 Pedersen SB, Kristensen K, Fisker S, Jorgensen JO, Christiansen JS \& Richelsen B. Regulation of uncoupling protein-2 and -3 by growth hormone in skeletal muscle and adipose tissue in growth hormone-deficient adults. Journal of Clinical Endocrinology and Metabolism $1999 \mathbf{8 4}$ 4073-4078.

10 Byatt JC, Staten NR, Salsgiver WJ, Kostelc JG \& Collier RJ. Stimulation of food intake and weight gain in mature female rats by bovine prolactin and bovine growth hormone. American Journal of Physiology 1993264 E986-E992.

11 Roberts TJ \& Azain MJ. Effect of somatotropin on rate and composition of gain and feed intake in young, pituitary intact female rats. Growth, Development and Aging 199559 3-13.

12 Roberts TJ, Azain MJ, White BD \& Martin RJ. Rats treated with somatotropin select diets higher in protein. Journal of Nutrition $19951252669-2678$.

13 Malmlof K, Johansen PB, Haahr PM, Wilken M \& Oxlund H. Methylprednisolone does not inhibit the release of growth hormone after intravenous injection of a novel growth hormone 
secretagogue in rats. Growth Hormone and IGF Research 19999 $445-450$.

14 Johansen T, Deckert M, Mandrup-Poulsen T \& Malmlof K. The role of growth hormone and glucocorticoid in glucose handling in vivo. Journal of Endocrinology 1999162 87-93.

15 Rolls BJ, Rowe EA \& Turner RC. Persistent obesity in rats following a period of consumption of a mixed, high energy diet. Journal of Physiology 1980298 415-427.

16 Azain MJ, Hausman DB, Kasser TR \& Martin RJ. Effect of somatotropin and feed restriction on body composition and adipose metabolism in obese Zucker rats. American Journal of Physiology 1995269 E137-E144.

17 Martin RJ, Drewry M, Jewell D, Harris RB, Young R \& Patton JS Growth hormone treatment reduces total body fat accumulation in Zucker obese rats. International Journal of Obesity 198913 $327-335$.

18 Aroniadou-Anderjaska V, Lemon PW \& Gilloteaux J. Effects of exogenous growth hormone on skeletal muscle of young female rats. Tissue and Cell $1996 \mathbf{2 8} 719-724$.

19 Wolthers T, Grofte T, Jorgensen JO, Moller N, Vahl N, Christiansen JS et al. Effects of growth hormone $(\mathrm{GH})$ administration on functional hepatic nitrogen clearance: studies in normal subjects and GH-deficient patients. Journal of Clinical Endocrinology and Metabolism 199478 1220-1224.

20 Malmlof K, Cortova Z, Saxerholt H, Karlsson E, Arrhenius-Nyberg V \& Skottner A. Effects of insulin-like growth factor-I and growth hormone on the net flux of amino acids across the hind limbs in the surgically traumatized pig. Clinical Science 199588 285-292.

21 Camps L, Reina M, Llobera M, Vilaro S \& Olivecrona T. Lipoprotein lipase: cellular origin and functional distribution. American Journal of Physiology 1990258 C673-C681.

22 Fielding BA \& Frayn KN. Lipoprotein lipase and the disposition of dietary fatty acids. British Journal of Nutrition $1998 \mathbf{8 0} 495-502$.

23 Blissett J, Harris G \& Kirk J. Effect of growth hormone therapy on feeding problems and food intake in children with growth disorders. Acta Paediatrica $200089644-649$.

24 Roberts TJ \& Azain MJ. Somatotropin treatment reduces energy intake without altering protein intake in pigs selecting between high and low protein diets. Journal of Nutrition 1997127 2047-2053.

25 Bareille N, Faverdin P \& Hay M. Modification of feed intake response to a beta 2 -agonist by bovine somatotropin in lactating or dry dairy cows. Journal of Dairy Science 199780 52-66.

26 Siebrits FK \& Barnes PM. The change in the rate of muscle protein metabolism of rats from weaning to 90 days of age. Comparative and Biochemical Physiology A 198992 485-488.

Received 6 April 2001

Accepted 12 September 2001 